\title{
Klinik Örneklerden İzole Edilen Acinetobacter baumannii ve Pseudomonas aeruginosa Suşlarının Sınıf 1 ve 2 İntegron Taşıyıcılığı ve Yeni Bir Gen Kaseti Birlikteliği: bla ${ }_{\text {OXA-11 }}$-cmIA7
}

\section{Carriage of Class 1 and 2 Integrons in Acinetobacter baumannii and Pseudomonas aeruginosa Isolated from Clinical Specimens and a Novel Gene Cassette Array: bla $a_{\text {OXA-11 }}-\mathrm{Cm} / A 7$}

\author{
Fırat Zafer MENGELOĞLU ${ }^{1}$, Ayşegül ÇOPUR ÇiçEK² ${ }^{2}$ Esra KOÇOĞLU ${ }^{1}$, Cemal SANDALLI ${ }^{3}$, \\ Emine Esra BUDAK ${ }^{3}$, Osman Birol ÖZGÜMÜş ${ }^{2}$

\footnotetext{
${ }^{1}$ Abant İzzet Baysal Üniversitesi Tıp Fakültesi, Tıbbi Mikrobiyoloji Anabilim Dalı, Bolu.

${ }^{1}$ Abant Izzet Baysal University Faculty of Medicine, Department of Medical Microbiology, Bolu, Turkey.

${ }^{2}$ Recep Tayyip Erdoğan Üniversitesi Tıp Fakültesi, Tıbbi Mikrobiyoloji Anabilim Dalı, Rize.

2 Recep Tayyip Erdogan University Faculty of Medicine, Department of Medical Microbiology, Rize, Turkey.

${ }^{3}$ Recep Tayyip Erdoğan Üniversitesi Fen Edebiyat Fakültesi, Biyoloji Bölümü, Rize.
} \\ ${ }^{3}$ Recep Tayyip Erdogan University Faculty of Arts and Sciences, Department of Medical Biology, Rize, Turkey.
}

Geliş Tarihi (Received): 24.09.2013 • Kabul Ediliş Tarihi (Accepted): 19.11.2013

ÖZET

Antibiyotik direnç genlerinin bakteriler arasındaki yayılımı, enfeksiyon hastalıklarının tedavisinde ciddi sorunlar oluşturmaktadır. Son zamanlarda bu genlerin integronlarda da taşındığı gösterilmiştir. Ülkemizde, Acinetobacter baumannii ve Pseudomonas aeruginosa klinik izolatlarında sınıf 1 ve sınıf 2 integron taşıyıcılığıyla ilgili çalışmalar sınırlı sayıdadır. Bu çalışmada, Abant İzzet Baysal Üniversitesi Hastanesinde, klinik örneklerden izole edilen A.baumannii ve P.aeruginosa suşlarında, sınıf 1 ve 2 integron taşıyıcılığının araştırıması ve antibiyotik direnç gen kasetlerinin dizi analiziyle karakterize edilmesi amaçlanmıştır. Çalışmaya, Mart 2010-Aralık 2012 tarihleri arasında çeşitli klinik örneklerden (\%56 balgam, \%19 yara, \%11 idrar, \%11 kan, \%3 kateter) izole edilen 77 A.baumannii ve 60 P.aeruginosa olmak üzere toplam 137 suş dahil edilmiştir. İzolatların tanımlanması ve antibiyogramları Vitek 2 Compact (bioMérieux, Fransa) ve BD Phoenix 100 (Becton Dickinson, ABD) sistemleriyle yapılmıştır. Suşlarda integron varlığı, sınıf 1 (int/1) ve sınıf 2 (int/2) integraz bölgeleri için özgül primer çiftleri kullanılarak PCR yöntemiyle araştııılmış; integron amplifikasyonunun gerçekleştirildiği tüm örnekler, hem klonlanarak hem de PCR ürünü olarak DNA dizi analizine tabi tutulmuştur. Çalışmada, A.baumannii suşlarında en yük- 
sek duyarlılık kolistin (\%96) ve tigesiklin (\%78), P.aeruginosa suşlarında ise piperasilin-tazobaktam (\%97) ve piperasiline (\%93) karşı saptanmış; buna karşın A.baumannii suşlarında en yüksek direnç oranı (\%95) piperasilin/tazobaktama karşı gözlenmiştir. A.baumannii suşlarının \%33 (26/77)'ünde, P.aeruginosa suşlarının ise \%10 (6/60)'unda int/1 geni tespit edilmiş; int/1 pozitif suşlarda değişken bölgeler PCR ile çoğaltıldığında sekiz $(8 / 77, \% 10)$ A.baumannii ve üç $(3 / 60, \% 5)$ P.aeruginosa suşunun antibiyotik direnç gen kaseti taşıdığı belirlenmiştir. Suşların hiçbirisinde int/2 geni saptanmamıştır. İntegron pozitif olan tüm A.baumannii suşlarında piperasilin/tazobaktam, seftazidim, sefepim, seftriakson ve ampisilin/sulbaktama karşı, integron pozitif tüm P.aeruginosa suşlarında ise seftazidim, gentamisin ve siprofloksasine karşı ortak direnç paterni tespit edilmiştir. İntegronların DNA dizi analizleri, A.baumannii [aacC1-aadA1 ve aac(3)-1] ve P.aeruginosa (bla $a_{\mathrm{OXA}-30}$-aadA1 ve bla $\left.{ }_{\mathrm{OXA}-11^{-}} \mathrm{Cm} / A 7\right)$ suşlarının ikişer farklı gen kaset dizisi taşıdığını göstermiştir. Ulaşabildiği kadarılla, P. aeruginosa integron gen kaseti içerisinde tanımlanan bla ${ }_{\mathrm{OXA}-11}{ }^{-\mathrm{Cm} I A 7}$ gen dizilimi ilk kez bu çalışma ile tanımlanmış ve yeni bir gen dizilimi olarak literatüre sunulmuştur.

Anahtar sözcükler: Pseudomonas aeruginosa; Acinetobacter baumannii; integron; gen kaseti.

\section{ABSTRACT}

The dissemination of antibiotic resistance genes between bacteria leads to serious problems in the treatment of infectious diseases. It has been shown that resistance genes can also be carried by the integrons. There are limited studies regarding the carriage of class 1 and 2 integrons in Acinetobacter baumannii and Pseudomonas aeruginosa clinical strains in Turkey. The aims of this study were to investigate the carriage rates of class 1 and class 2 integrons in A.baumannii and P.aeruginosa strains isolated from clinical samples in Abant Izzet Baysal University Hospital, and to characterize the antibiotic resistance gene cassettes in these integrons by sequence analyses. A total of 137 strains (77 A.baumannii and 60 P.aeruginosa) isolated from various clinical specimens ( $56 \%$ were sputum, $19 \%$ wound, $11 \%$ urine, $11 \%$ blood, 3\% catheter), between March 2010-December 2012, were included in the study. The identification and antibiotic susceptibility tests of the isolates were performed by Vitek 2 Compact (bioMérieux, France) and BD Phoenix 100 (Becton Dickinson, USA) systems. The presence of integrons were screened by PCR method using specific primer pairs targeting class 1 (int/1) and 2 (int/2) integrase regions. All the samples that revealed integron amplification were subjected to DNA sequence analysis, both in the forms of cloned products and PCR amplicons. In the study, the highest susceptibility rates were found against colistin (96\%) and tigecycline (78\%) in A.baumannii, and against piperacillin/tazobactam (97\%) and piperacillin (93\%) in P.aeruginosa isolates. The highest resistance rate was determined for piperacillin/tazobactam (95\%) in A.baumannii strains. The presence of int/1 gene was detected in 33\% (26/77) of A.baumannii and $10 \%(6 / 60)$ of P.aeruginosa isolates. When variable regions in int/1 positive strains were amplified by PCR, eight $(8 / 77,10 \%)$ A.baumannii and three $(3 / 60,5 \%)$ P.aeruginosa strains were found to harbor antibiotic resistance gene cassettes. Int/2 gene was not detected in any of the isolates. Resistance to piperacillin/tazobactam, ceftazidime, cefepime, ceftriaxone and ampicillin/sulbactam was detected as the common resistance pattern in all integron-positive A.baumannii strains, whereas resistance to ceftazidime, gentamicin and ciprofloxacin was the common pattern in all integron-positive P.aeruginosa strains. DNA sequence analysis of variable regions of integrons indicated that two separate gene cassette arrays (aacC1-aadA1 and aac(3)-1) were carried by A.baumannii strains, and two types of

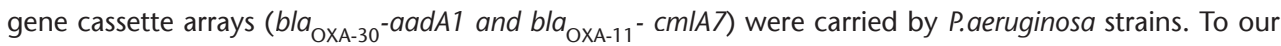
best knowledge, this is the first report of the gene sequence of bla $a_{\mathrm{OXA}-11}-\mathrm{Cm} / A 7$ defined in an integron gene cassette of P.aeruginosa.

Key words: Pseudomonas aeruginosa; Acinetobacter baumannii; integron; gene casette. 


\section{Giriş}

Pseudomonas aeruginosa ve Acinetobacter baumannii, yoğun bakım üniteleri başta olmak üzere hastane enfeksiyonlarında en sık izole edilen bakteriler olup, tedavilerinde en önemli problem, çoğul dirençli suşların sayısında artış ve bunun sonucunda tedavide kullanılacak antibiyotik seçeneklerinde azalmadır ${ }^{1-6}$. Antimikrobiyal ilaç direncinin, bakteriler arasında yayılmasında en etkili mekanizmalardan biri konjugasyondur. Konjugasyonda direnç genlerini taşıyan R-plazmidleri diğer DNA molekülleri gibi, transpozon veya integronları da taşıyabilirler. Transpozon ve integronlar, bir DNA molekülünden diğerine, homolog olmayan bölgelere integre olmak suretiyle transloke olabilen (yer değiştirebilen) DNA elementleridir. Son yıllarda dikkatler, bakterilerde genetik birimlerin transferine, yani mobil gen kasetleri ve integronlar üzerinde yoğunlaşmıştır. Gen kasetleri, genelde konak hücre DNA'sına integre olmuş gen topluluklarıdır7,8. Antibiyotik direnç integronları terimi ise ilk kez Rowe-Magnus ve arkadaşları ${ }^{9}$ tarafından kullanılmıştır. Direnç genlerini taşıyan plazmidler bakteriler arasında transdüksiyon, transformasyon, konjugasyon ve transpozisyon gibi mekanizmalarla aktarılırlar. Bu rekombinasyon, integron denilen farklı bir DNA ailesi tarafından oluşturulmaktadır. İntegronlar antibiyotik direnç determinantlarını kodlayan, belirli gen kasetlerini entegre etme veya taşıma yeteneğine sahip genetik elemanlardır. Sınıf 1 integronun yapısında bir 5'- ve 3'- korunmuş segment (5'-CS ve $3^{\prime}$-CS) ve bir de değişken bölge vardır. 5'-CS, intl geni (integraz) ve eklenen gen(ler)in ekspresyonu için kullanılan bir promoter bölge içerirken, 3'-CS defektif kuaterner amonyum direnç geni qacE $\Delta 1$ ve sülfonamide direnç sağlayan sull geni içerir $^{10,11}$. İki korunmuş bölge arasında bulunan değişken bölge, antibiyotik direnç gen kasetlerinin girmesi için rekombinasyon yeridir. Sınıf 2 integronlar ise dihidrofolat redüktaz gen kaseti içermektedir ve sırasıyla trimetoprim, streptotrisin ve streptomisin/spektinomisine direnç sağlayan dfrA1, sat2 ve aadA1 gibi üç klasik gen kaseti taşımaktadır.

Integronların tek başlarına hareket yetenekleri yoktur ve aynı zamanda içlerinde bir ya da daha fazla gen kaseti taşıyabilirler. Bir bakteride birden fazla integron bulunabilir; gen kasetlerinin düzeyi ve ekspresyonu, bakteride bulunan integron sayısına ve $5^{\prime}$ bölgesinde bulunan promotor bölgesinin aktif olmasına bağlıdır ${ }^{12,13}$. Integronlar, plazmid veya transpozonların içerisinde bulunduklarından dolayı, bir bakteriden diğerine, hatta integronlar içerisinde yer alan gen kasetleri bir integrondan diğerine geçebilme özelliğine sahiptirler. Bu durum, antibiyotik direnç determinantlarının yayılmasına neden olmaktadır. Bu çalışmada, klinik örneklerden izole edilen P.aeruginosa ve A.baumannii suşlarının sınıf 1 ve sınıf 2 integronlar yönünden taranması ve taşıdıkları gen kasetlerinin karakterize edilmesi amaçlanmıştır.

\section{GEREÇ ve YÖNTEM}

\section{Suşlar ve Antimikrobiyal Duyarlılık Testleri}

Çalışmaya, Abant İzzet Baysal Üniversitesi Tıp Fakültesi Hastanesinde, Mart 2010-Aralık 2012 tarihleri arasında mikrobiyoloji laboratuvarına gönderilen çeşitli klinik örneklerden izole edilen 77 A.baumannii ve 60 P.aeruginosa suşu dahil edildi. İzolatların tanımlanması ve antibiyogramları Vitek 2 Compact (bioMérieux, Fransa) ve BD Phoenix 100 (Becton 
Dickinson, $A B D$ ) otomatize sistemleri kullanılarak yapıldı. Antimikrobiyal duyarlılık deneyleri CLSI (Clinical and Laboratory Standards Institute) kriterlerine uygun olarak değerlendirildi ${ }^{14}$. Acinetobacter suşlarının tigesiklin ve kolistine duyarlılıkları BSAC (British Society for Antimicrobial Chemotherapy) kriterlerine göre yorumlandı ${ }^{15}$.

P.aeruginosa suşları için amikasin (AK), gentamisin (GN), siprofloksasin (CiP), seftazidim (CAZ), piperasilin (PRL), piperasilin-tazobaktam (TZP), aztreonam (ATM), meropenem (MEM), sefepim (FEP) ve imipenem (IPM) duyarlılığ; A.baumannii için AK, GN, CiP, CAZ, TZP, FEP, IPM, tetrasiklin (TE), seftriakson (CRO), sulbaktam/ampisilin (SAM), trimetoprim-sülfametoksazol (SXT), tobramisin (TOB), kolistin (CT) ve tigesiklin (TCC) duyarlılığı değerlendirildi. Kalite kontrol suşu olarak P.aeruginosa ATCC 27853 kullanıldı.

\section{Total DNA İzolasyonu ve İntegrona Özgül Polimeraz Zincir Reaksiyonu (PCR)}

Kalıp DNA eldesi için bakteri suşları $3 \mathrm{ml}$ Luria-Bertani (LB) sıvı besiyerine (\%1 tripton, $\% 0.5$ maya ekstraktı, \%0.5 NaCl, pH 7.4) inoküle edildi ve 16 saat $37^{\circ} \mathrm{C}^{\prime}$ de çalkalamalı inkübatörde üretildi. Kültürün 1.5 ml'si ependorf tüpüne alınarak 10.000 rpm'de 5 dk çöktürüldü. Çökelti sıvısının üst kısmı atıldı; çökeltideki hücreler $500 \mu$ l deiyonize suda çözüldü ve $95^{\circ} \mathrm{C}^{\prime}$ de $10 \mathrm{dk}$ ısıtılarak parçalandı. Preparat, $13.000 \mathrm{rpm}$ 'de $5 \mathrm{dk}$ santrifüjlenerek çöktürüldü. Üst kısmın 1-3 $\mu$ l'si PCR'de kalıp DNA olarak kullanıldı ${ }^{16}$.

Bütün izolatlar, öncelikle korunmuş sınıf 1 (int/1) ve sınıf 2 (int/2) integraz bölgeleri için araştırıldı. Bu amaçla, intı1 için intı1F (ACATGTGATGGCGACGCACGA) ve intl1R (ATTTCTGTCCTGGCTGGCGA); int/2 için intl2F (CACGGATATGCGACAAAAAGGT) ve intl2R (GTAGCAAACGAGTGACGAAATG) primer çiftleri kullanıldı. int/1 bölgesi için pozitif sonuç alındığında, 5'-CS ileri primeri (GGCATCCAAGCAGCAAG) ve 3'-CS geri primeri (AAGCAGACTTACCTGA) kullanılarak değişken bölgeler çoğatıldı ${ }^{10}$. Standart PCR karışımları $50 \mu$ l son hacim olacak şekilde; 1.5 ünite DNA polimeraz I (GoTaq, Promega), $5 \mu \mathrm{l}$ DNA, $10 \mu \mathrm{l}$ XX DNA polimeraz tamponu (Promega), $3 \mu \mathrm{l} 1.5 \mathrm{mM} \mathrm{MgCl}_{2}, 5 \mu \mathrm{l} 2 \mathrm{mM}$ her bir dNTP ve $2 \mu \mathrm{l}$ her bir primer stoğu $(25 \mathrm{pmol} / \mu \mathrm{l})$ ve son hacim steril deiyonize su ile $50 \mu l^{\prime}$ ye tamamlanarak hazırlandı. Amplifikasyon koşulları; $5 \mathrm{dk} 96^{\circ} \mathrm{C}, 1 \mathrm{dk} 55^{\circ} \mathrm{C}, 3 \mathrm{dk}$ $70^{\circ} \mathrm{C}$ (bir döngü); 15 sn $96^{\circ} \mathrm{C}, 30$ sn $55^{\circ} \mathrm{C}, 3 \mathrm{dk} 70^{\circ} \mathrm{C}$ (24 döngü) ve son sentez $5 \mathrm{dk}$ $70^{\circ} \mathrm{C}$ (bir döngü) olacak şekilde programlandı ${ }^{10}$. Amplifikasyon ürünleri \%1.4'lük agaroz jelde yürütüldü ve görüntülendi. İntegron amplifikasyonunun gerçekleştirildiği tüm örnekler, hem klonlanarak hem de PCR ürünü olarak baz dizisi analizine tabi tutuldu.

\section{Agaroz Jel Elektroforezi ve DNA Klonlama}

Plazmidler ve PCR ürünleri agaroz jel elektroforezinde yürütülerek UV'de görüntülendi. Plazmidler için \%1'lik, PCR ürünleri için ise \%1.4'lük agaroz jel $(0.5 \mu \mathrm{g} / \mathrm{ml}$ etidyum bromür katkılı) kullanıldı. Yürütme, 100V doğru akım altında 45 dakika olarak gerçekleştirildi. Tam integron genleri çoğaltıldı ve üretilen PCR ürünlerinin, pGEM-T klonlama vektörüne ligasyonu üretici firmanın önerileri doğrultusunda sağlandı. Ligasyon ürünleri, E.coli DH5 $\alpha$ kompetan hücrelerine Isı şoku ile transforme edildi. Transformasyon sonrası hücreler ampisilin, IPTG ve X-gal içeren seçici LB agara ekilerek mavi/beyaz koloni oluşumuna bakıldı ve beyaz kolonilerden plazmid izole edilerek pozitif klonlar belirlendi ${ }^{17}$. İzole edilen bu plazmidler EcoRI restriksiyon enzimi ile kesilerek ayrıca doğrulandı. Pozitif 
olduğu doğrulanan plazmidleri içeren rekombinant hücreler tekrar çoğaltılarak plazmid DNA saflaştırma kiti kullanılarak DNA dizi analizi için tekrar izole edildi. İzole edilen plazmid DNA örnekleri baz dizisi analizi için Macrogen firmasına (Amsterdam, Hollanda) gönderildi ve hem T7 promotor hem de SP6 bölgelerinden dizi analizi gerçekleştirildi. PCR ürünlerinden de teyit amaçlı dizi analizi yapıldı ve PCR ürünlerinin baz dizisi analizi, değişken bölgeleri çoğaltmak için kullanılan $5^{\prime} \mathrm{CS}$ ve $3^{\prime} \mathrm{CS}$ primerleri ile gerçekleştirildi ${ }^{18}$. Dizileme sonuçları NCBI biyoinformatik sitesi kullanılarak analiz edildi.

\section{BULGULAR}

Çalışmaya alınan 77 A.baumannii suşunun \%49.4'ü balgam, \%20.8'i yara, \%18.2'si kan, \%9.1'i idrar ve \%2.6'sı kateter örneklerinden; 60 P.aeruginosa suşunun ise \%62.7'si balgam, \%16.9'u yara, \%13.6'sı idrar ve \%3.4'ü kan örneklerinden izole edilmiştir. İzolatların antibiyotiklere karşı duyarlılık oranları Tablo I'de görülmektedir. Buna göre A.baumannii suşlarında en yüksek duyarlılık kolistin (\%96.1) ve tigesikline (\%78), P.aeruginosa suşlarında ise piperasilin-tazobaktam (\%96.6) ve piperasiline (\%93.2) karşı saptanmıştır (Tablo I).

\begin{tabular}{|c|c|c|c|c|c|c|}
\hline \multirow[b]{2}{*}{ Antibiyotik } & \multicolumn{3}{|c|}{ Acinetobacter baumannii $(\mathrm{n}=77)$} & \multicolumn{3}{|c|}{ Pseudomonas aeruginosa $(n=60)$} \\
\hline & $\begin{array}{l}\text { Duyarlı } \\
\text { n (\%) }\end{array}$ & $\begin{array}{c}\text { Orta duyarlı } \\
\text { n (\%) }\end{array}$ & $\begin{array}{c}\text { Dirençli } \\
\text { n (\%) }\end{array}$ & $\begin{array}{l}\text { Duyarlı } \\
\text { n (\%) }\end{array}$ & $\begin{array}{c}\text { Orta duyarlı } \\
\text { n (\%) }\end{array}$ & $\begin{array}{c}\text { Dirençli } \\
\text { n (\%) }\end{array}$ \\
\hline PRL & - & - & - & $56(93.2)$ & $1(1.7)$ & $3(5.1)$ \\
\hline TZP & $3(3.9)$ & $1(1.3)$ & $73(94.8)$ & $58(96.6)$ & 0 & $2(3.4)$ \\
\hline SAM & $5(6.5)$ & $5(6.5)$ & $67(87)$ & - & - & - \\
\hline CAZ & $4(5.2)$ & $2(2.6)$ & $71(92.2)$ & $50(83.1)$ & $1(1.7)$ & $9(15.3)$ \\
\hline FEP & $6(7.8)$ & 0 & $71(92.2)$ & $52(86.4)$ & $4(6.8)$ & $4(6.8)$ \\
\hline CRO & $4(5.2)$ & $1(1.3)$ & $72(93.5)$ & - & - & - \\
\hline ATM & - & - & - & $42(69.5)$ & $12(20.3)$ & $6(10.2)$ \\
\hline IPM & $13(16.9)$ & $8(6.5)$ & $59(76.6)$ & $50(83.1)$ & $1(1.7)$ & $9(15.3)$ \\
\hline MEM & - & - & - & $54(88.1)$ & $1(1.7)$ & $5(8.5)$ \\
\hline TOB & $45(58.4)$ & 0 & $32(41.6)$ & - & - & - \\
\hline $\mathrm{AK}$ & $11(14.3)$ & $3(3.9)$ & $63(81.8)$ & $52(86.4)$ & $1(1.7)$ & 7 (11.9) \\
\hline GN & $35(45.5)$ & $6(7.8)$ & $36(46.8)$ & $47(78)$ & $5(8.5)$ & 8 (13.6) \\
\hline SXT & $16(20.8)$ & $2(2.6)$ & $59(76.6)$ & - & - & - \\
\hline $\mathrm{TE}$ & $17(22.1)$ & $8(10.4)$ & $52(67.5)$ & - & - & - \\
\hline TGC & 70 (77.9) & $17(22.1)$ & 0 & - & - & - \\
\hline Cip & $5(6.5)$ & 0 & $72(93.5)$ & $49(81.4)$ & $1(1.7)$ & $10(16.9)$ \\
\hline $\mathrm{CT}$ & $74(96.1)$ & 0 & $3(3.9)$ & - & - & - \\
\hline
\end{tabular}


A.baumannii suşlarının \%33 (26/77)'ünde intl1 geni tespit edilmiş; int/1 pozitif suşlarda değişken bölgeler PCR ile çoğaltıldığında 8 (\%30.7) suşun antibiyotik direnç gen kaseti taşıdığı belirlenmiştir. Tüm suşlarda ise \%10.1 oranında gen kaseti taşıyan integron saptanmıştır. DNA dizi analizleriyle gen kasetlerinin aacC1-aadA1 ve $\operatorname{aac}(3)$-I diziliminde iki farklı tipte olduğu belirlenmiştir. aacC1 geni aminoglikozid N(3') asetiltransferaz enzimi kodlamaktadır ve gentamisine direnç sağlamaktadır. aadA1 geni aminoglikozid adeniltransferaz enzimi kodlamaktadır ve streptomisin/spektinomisine direnç sağlamaktadır. aac(3)-I geni ise aminoglikozid 3-N-asetil transferaz enzimini kodlamaktadır ve gentamisin, sisomisin ve fortimisine direnç sağlamaktadır. Yedi Acinetobacter suşunun aacC1-aadA1 dizilimine sahip sınıf 1 integron taşıdığı belirlenirken, bir Acinetobacter'in aac(3)-I kaseti içeren sınıf 1 integron taşıdığı belirlenmiştir (Tablo II). Tespit edilen sınıf 1 integronların genetik yapıları Şekil 1'de şematik olarak gösterilmiştir. Bakteri suşlarının hiçbirinde int/2 integraza rastlanmamıştır.

P.aeruginosa suşlarının \%10 (6/60)'unda int/1 geni belirlenmiş; int/1 pozitif suşlarda değişken bölgeler PCR ile çoğaltıldığında 3 (\%50) suşun antibiyotik gen kaseti taşıdığı belirlenmiştir. Tüm suşlarda ise \%5 oranında gen kaseti taşıyan integron saptanmıştır. Gen kasetlerinin bla ${ }_{\text {OXA-30 }}$-aadA1 ve bla $a_{\text {OXA-11 }}-\mathrm{Cm} / A 7$ diziliminde iki farklı tipte olduğu izlenmiştir. İki örneğin bla OXA-30-aadA1 dizilimine, bir örneğin cmlA17-bla OXA-11 dizilimine sahip olduğu saptanmıştır (Tablo II). bla $a_{\mathrm{OXA}-11}-\mathrm{cm} / A 7$ gen kaset dizilimi yeni bir kombinasyon olup, genetik yapısı Şekil 1'de şematik olarak gösterilmektedir. bla ${ }_{\text {OXA-11 }}$ geni grup 1 okzasilinaz enzimleri, bla ${ }_{\mathrm{OXA}-30}$ geni ise grup 3 okzasilinaz enzimleri kodlamaktadır ve beta-laktamlara direnç sağlamaktadır. cmIA7 geni kloramfenikol direnç proteini kodlamaktadır ve kloramfenikole enzimatik olmayan bir yolla direnç sağlamaktadır.

Suşların epidemiyolojik özellikleri Tablo II'de görülmektedir. Üç Pseudomonas suşu (P23, P44 ve P60) aynı hastanın farklı zaman ve klinik materyallerinden izole edilmiş, farklı fenotip ve genotipteki etkeni olarak tespit edilmiştir (Tablo II). Örneklerin hiçbirinde int/2 geni saptanmamıştır. İntegron pozitif olan tüm A.baumannii suşlarında piperasilin/tazobaktam, seftazidim, sefepim, seftriakson ve ampisilin/sulbaktam antibiyotiklerine karşı, integron pozitif tüm P.aeruginosa suşlarında ise seftazidim, gentamisin ve siprofloksasin antibiyotiklerine karşı direnç ortak olarak gözlenmiştir.

\section{TARTIŞMA}

Bakteriler arasında beta-laktamlar, kinolonlar, karbapenemler ve aminoglikozidlere direncin hızlı yayılımı, enfeksiyon hastalıklarında ciddi ve artan bir sorundur. Son çalışmalar direnç genlerinin integronlar ile yayılabileceğini göstermektedir ${ }^{1,2}$. İntegron gen kasetlerinde çok sayıda farklı direnç genleri bulunabilir. Farklı sınıftan beta-laktamaz genleri (A, B ve D sınıfı) ile aminoglikozid direnç genleri integron gen kasetleri içerisinde bulunabilir. Aminoglikozid modifiye edici enzimlerin (AMEs) üretimi, bakterilere antibiyotiklerin amino ve hidroksil fonksiyonlarını modifiye etme yeteneği kazandırır. Bu yetenek bakterilerin aminoglikozidlere direnç göstermesinin en önemli yoludur. AMEs, aminoglikozid asetiltransferaz (AAC), aminoglikozid adeniltransferaz (AAD), aminoglikozid fosfotransferaz (APH) ve bu enzimlerin izoenzimlerini kapsar ${ }^{19}$. Sunulan bu çalışma- 


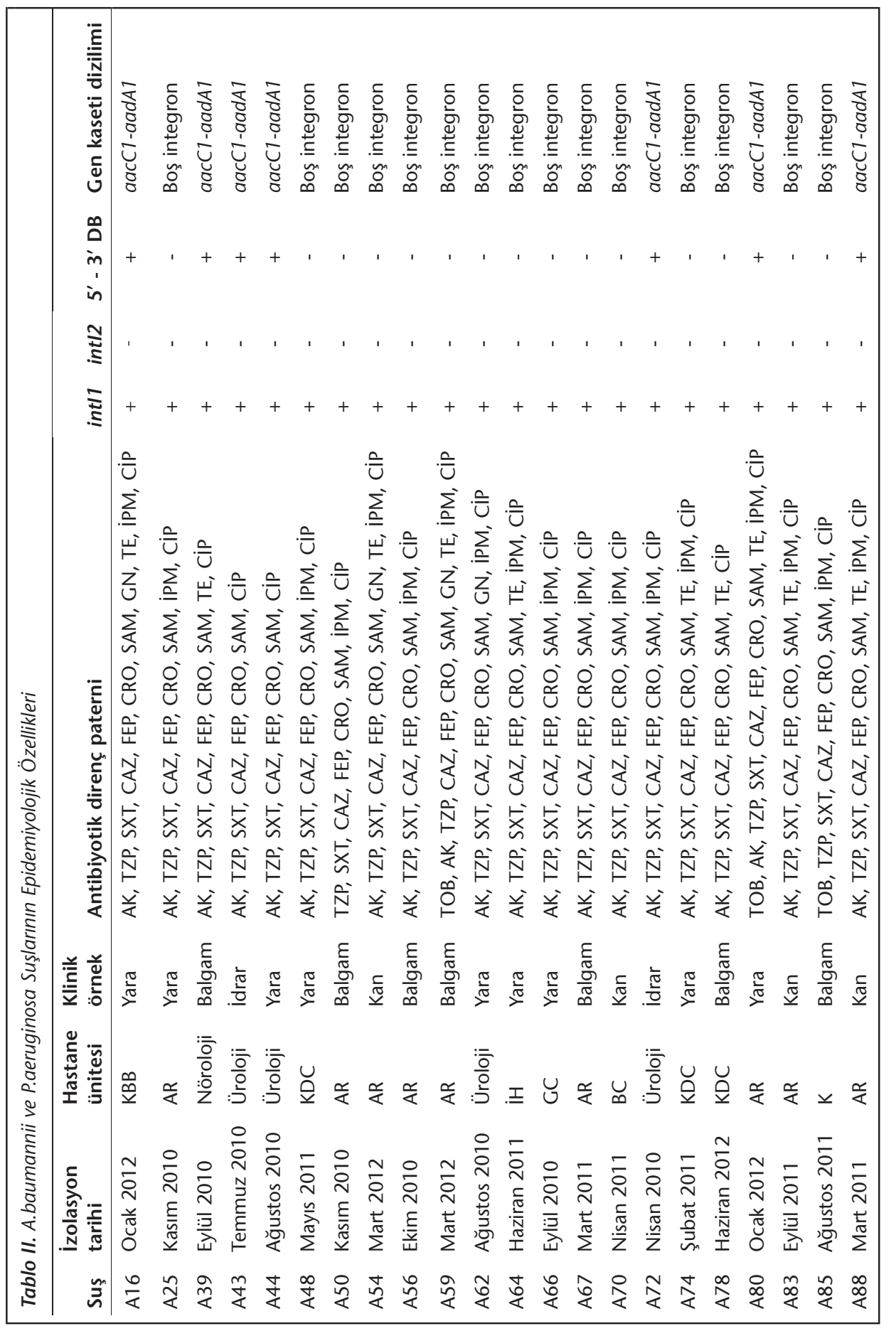




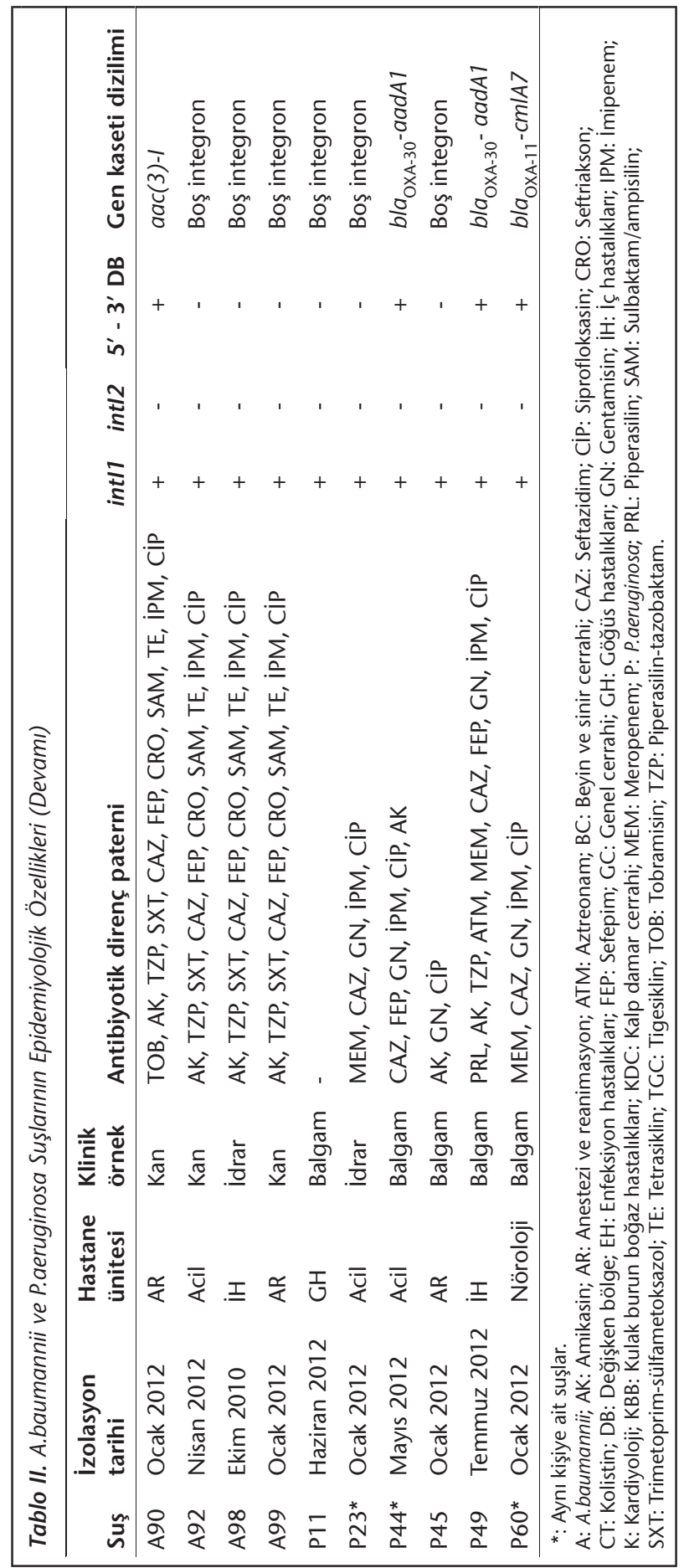




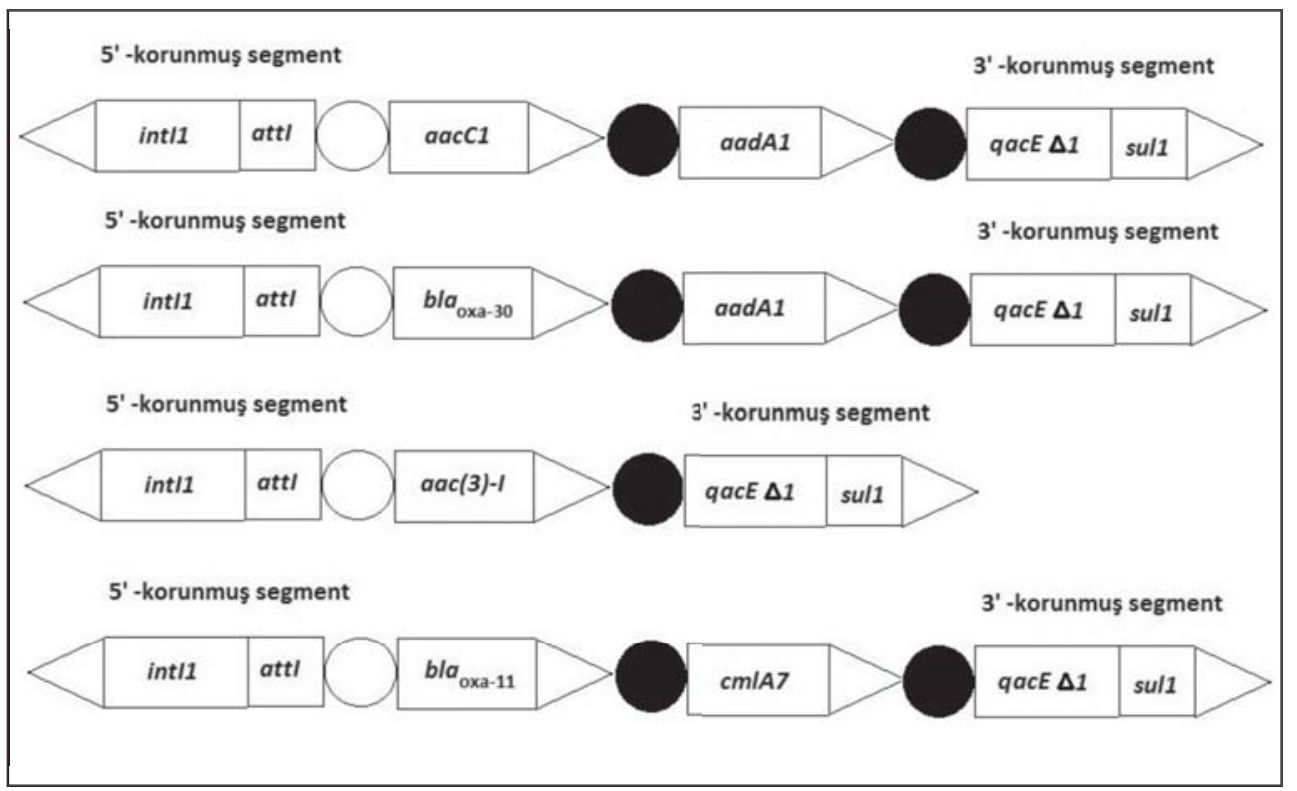

Şekil 1. A.baumannii ve P.aeruginosa suşlarında tespit edilen sınıf 1 integronların genetik yapılarının şematik gösterimleri [Siyah daireler integronun 59-baz elemanlarını (rekombinasyon bölgeleri), beyaz daireler ise integraz (attl) bölgesini göstermektedir. qacE 1 kuaterner amonyum maddelerine direnç geni, sul1 ise sülfanomidlere direnç genidir).

da, A.baumannii' de AAC ve AAD varyantlarının baskın olarak bulunduğu, P.aeruginosa'da ise AAD varyantının bulunduğu gösterilmiştir. Her iki türde aminoglikosidaz enzimlerinin üretilmesi, bu türlere ait suşlarda aminoglikozid direncinin nedenini ve aktarılabilme potansiyelini göstermektedir. Beta-laktamaz genlerinden D sınıfına ait okzasilinaz kodlayan OXA-11 ve OXA 30 alelleri ise sadece P.aeruginosa'da integron gen kasetleri içerisinde belirlenmiştir. OXA-tipi beta-laktamazlar oksasilin ve kloksasilini parçalayarak direnç oluştururlar. İki P.aeruginosa suşunda OXA-tipi beta-laktamaz kodlayan genlerin integronlar üzerinde bulunması, bu genin P.aeruginosa suşundan başka suş veya türlere aktarılmasına aracılık edebilir.

Bakterilerde bulunan $\mathrm{cml}$ direnç genleri, kloramfenikol antibiyotiğine karşı direnç oluşturmaktadır. Türkiye'den bildirilen daha önceki bir çalışma, P.aeruginosa suşunda $\operatorname{aac}(3)-1 c-c m I A 5$ gen diziliminin integron 1 gen kaseti içerisinde olduğunu göstermiştir ${ }^{20}$. Literatür incelendiğinde, P.aeruginosa integron gen kaseti içerisinde bulunan bla ${ }_{\mathrm{OXA}-11}-\mathrm{cm} / \mathrm{A} 7$ gen diziliminin, daha önceden tespit edilemediğini ve ilk kez bu çalışma ile tanımlandığını göstermektedir.

İran'da 50 A.baumannii suşu ile yapılan bir çalışmada, integron pozitifliği \%88 olarak bulunmuş; integron pozitif 44 örneğin 21'inde sınıf 1,41'inde ise sınıf 1 ve sınıf 2 integron birlikte çoğaltılmıştı ${ }^{21}$. A.baumannii suşlarında integron varlığının araştırıldığı başka bir çalışmada, sınıf I integron pozitifliği \%92.5 oranında saptanmış, sınıf 2 integron pozitifliğine rastlanmamıştır ${ }^{22}$. Ülkemizden yapılan çok merkezli bir çalışmada, Çiçek 
ve arkadaşları ${ }^{23} 281$ A.baumannii suşundan sadece 18'inde sınıf 1 integron saptanırken, hiçbir suşta sınıf 2 integron tespit etmemişlerdir. Kiddee ve arkadaşları ${ }^{24}$, P.aeruginosa suşlarında yaptıkları integron tarama çalışmalarında, \%82 oranında sınıf 1 integron saptamışlar, integron gen kasetlerinde aminoglikozidlere direnç sağlayan birkaç farklı gen tespit etmişlerdir. İzmir'de yapılan bir çalışmada da, 163 gram-negatif bakterinin \%52.7'sinde sınıf 1 integron varlığı saptanmış; bu oranlar P.aeruginosa ve A.baumannii için sırasıyla \%49.3 ve \%57.8 olarak belirlenmiş, ancak sınıf 2 integron gen kasetine rastlanmamıştır ${ }^{25}$. Sınıf 2 integronlar 2009 yılına kadar Pseudomonas suşlarında ortaya çıkmamıştır. Çin'deki bir hastanede üç klinik Pseudomonas suşunun ilk defa hem sınıf 1 hem de sınıf 2 integron taşıdığı tespit edilmiştir ${ }^{26}$. Bizim çalışmamızda da 77 A.baumannii ve 60 P.aeruginosa suşunda, önce int/1 ve int/2 genleri taranmış ve pozitif gözlenen suşların değişken bölgeleri PCR ile çoğaltılmıştır. Çalışmamızda tespit edilen yeni gen kaset dizilimindeki $\mathrm{cmlA} 7$ geni her ne kadar klinik kullanımı sınırlı olan kloramfenikole karşı direnç sağlasa da, mobil direnç gen yapılarından olan integronların klinik kullanımdaki birçok antibiyotiğe karşı farklı direnç genlerini kazanarak plazmidlere geçişiyle yayılıma neden olabilecek potansiyelde olduklarını göstermektedir. Bu açıdan değerlendirildiğinde yeni gen kaseti dizilimlerinin ortaya çıkması bakteriyel popülasyonların devamlı antibiyotik baskısına maruz kaldığını ve direnç gelişiminin artan bir şekilde karşımıza çıkacağını göstermektedir.

Toplam örnek sayısı ( $n=137)$ dikkate alındığında Acinetobacter suşlarında gen kasetleri taşıyan integron pozitifliği \%10.1, Pseudomonas suşlarında ise \%5 olarak belirlenmiştir. Sonuçlar literatür ile karşılaştırıldığında hem A.baumannii hem de P.aeruginosa için integron gen kaseti taşıyıcılık oranı düşük bulunmuştur ${ }^{26,27}$. Sonuç olarak, ulaşabildiğimiz kadarıyla, P.aeruginosa integron gen kaseti içerisinde tanımlanan bla $a_{\mathrm{OXA}-11}-\mathrm{cmlA} 7$ gen dizilimi ilk kez bu çalışma ile tanımlanmıştır. Elde edilen veriler incelendiğinde sınırlı bir koleksiyonda bile yeni gen dizilimlerinin ve kombinasyonlarının belirlenebileceği gözlenmektedir. A.baumannii ve P.aeruginosa suşlarında mobil direnç genlerinden olan integronların bulunması, gelecekteki antimikrobiyal tedavilerin etkinliğine yönelik ciddi bir tehdit oluşturduğunu düşündürmektedir. Dolayısıyla, integron gen kasetlerindeki genlerin antibiyotik direncinin yayılmasına olan etkisinin dikkate alınması ve ülke genelinde çok merkezli takip çalışmalarının yürütülmesi gerektiği kanısına varılmıştır.

\section{KAYNAKLAR}

1. Strateva T, Yordanov D. Pseudomonas aeruginosa- a phenomenon of bacterial resistance. J Med Microbiol 2009; 58(9): 1133-48.

2. Towner KJ. Acinetobacter: an old friend, but a new enemy. J Hosp Infect 2009; 73(4): 355-63.

3. Maragakis LL, Perl TM. Acinetobacter baumannii: epidemiology, antimicrobial resistance, and treatment options. Clin Infect Dis 2008; 46(8): 1254-63.

4. Yıldırım MI, Tuğrul HM. Assessment of efficacies of imipenem, cefoperazon-sulbactam and sefepime in rats with experimental thigh abscess model Acinetobacter baumannii strains. Mikrobiyol Bul 2011; 45(3): 422-9.

5. Hosoglu S, Hascuhadar M, Yasar E, Uslu S, Aldudak B. Control of an Acinetobacter baumannii outbreak in a neonatal ICU without suspension of service: a devastating outbreak in Diyarbakir, Turkey. Infection 2012; 40(1): 11-8. 
Klinik Örneklerden İzole Edilen Acinetobacter baumannii ve Pseudomonas aeruginosa

Suşlarının Sınıf 1 ve 2 İntegron Taşıyıcılığı ve Yeni Bir Gen Kaseti Birlikteliği: bla ${ }_{\text {OxA-11 }}{ }^{-c m I A 7}$

6. Asık G. Current approaches to explain the virulence of Acinetobacter baumannii. Mikrobiyol Bul 2011; 45(2): 371-80.

7. Hall RM. Mobile gen casettes and integrons: capture and spread of genes by site-specific recombination. Mol Microbiol 1995;15(4): 593-600.

8. Fluit AC, Schmitz FJ. Class I integrons, gene casettes, mobility and epidemiology. Eur J Microbiol Infect Dis 1999; 18(11): 761-70.

9. Rowe-Magnus DA, Guerout AM, Mazel D. Bacterial resistance evolution by recruitment of super-integron gene cassettes. Mol Microbiol 2002; 43(6): 1657-79.

10. Lévesque C, Piche L, Larose C, Roy PH. PCR mapping integrons reveals several novel combinations of resistance genes. Antimicrob Agents Chemother 1995; 39(1): 185-91.

11. Bennett PM. Integrons and gene cassettes: a genetic construction kit for bacteria. J Antimicrob Chemother 1999; 43(1): 1-4.

12. Patridge S, Brown H, Hall R. Characterization and movement of the class 1 integron known as Tn2521 and Tn1405. Antimicrob Agents Chemother 2002; 46(5): 1288-94.

13. Solberg OD, Ajiboye RM, Riley LW. Origin of class 1 and 2 integrons and gene cassettes in a populationbased sample of uropathogenic Escherichia coli. J Clin Microbiol 2006; 44(4): 1347-51.

14. Clinical and Laboratory Standards Institute. Performance standards for antimicrobial susceptibility testing. $22^{\text {nd }}$ Informational Supplement, M100-S22, 2012. CLSI, Wayne, PA.

15. British Society for Antimicrobial Chemotherapy. BSAC methods for antimicrobial susceptibility testing. Version 12 May 2013. Available at: http://bsac.org.uk/wp-content/uploads/ 2012/02/Version-12-Apr-2013_final.pdf

16. Ausubel FM, Brent R, Kingston RE, et al (eds). Short Protocols in Molecular Biology. 1995, $2^{\text {nd }}$ ed. John Willey \& Sons, New York.

17. Aminov RI, Garrigues-Jeanjean N, Mackie RI. Molecular ecology of tetracycline resistance: development and validation of primers for detection of tetracycline resistance genes encoding ribosomal protection proteins. App Environ Microbiol 2001; 67(1): 22-32.

18. Bunny KL, Ruth, MH, Stokes HW. New mobile gene cassettes containing an aminoglycoside resistance gene, aacA7, and a chloramphenicol resistance gene, catB3, in an integron in pBWH301. Antimicrob Agents Chemother 1995; 39(3): 686-93.

19. Ramirez MS, Tolmasky ME. Aminoglycoside modifying enzymes. Drug Resist Update 2010; 13(6): 151-71.

20. Ozgumus OB, Caylan R, Tosun I, Sandalli C, Aydin K, Koksal I. Molecular epidemiology of clinical Pseudomonas aeruginosa isolates carrying the IMP-1 metallo- $\beta$-lactamase gene in a University Hospital in Turkey. Microb Drug Resist 2007; 13(3): 191-8.

21. Mirnejad R, Mostofi S, Masjedian F. Antibiotic resistance and carriage class 1 and 2 integrons in clinical isolates of Acinetobacter baumannii from Tehran, Iran. Asian Pac J Trop Biomed 2013; 3(2): 140-5.

22. Peymani A, Farajnia S, Nahaei MR, et al. Prevalence of class 1 integron among multidrug-resistant Acinetobacter baumannii in Tabriz, Northwest of Iran. Polish J Microbiol 2012; 61(1): 57-60.

23. Çiçek AÇ, Düzgün AÖ, Saral A, et al. Detection of class 1 integron in Acinetobacter baumannii isolates collected from nine hospitals in Turkey. Asian Pac J Trop Biomed 2013; 3(9): 743-7.

24. Kiddee A, Henghiranyawong K, Yimsabai J, Tiloklurs M, Niumsup PR. Nosocomial spread of class 1 integron-carrying extensively drug-resistant Pseudomonas aeruginosa isolates in a Thai hospital. Int J Antimicrob Agents 2013; 42(4): 301-6.

25. Eraç B, Hoşgör-Limoncu M, Ermertcan \$̧, Taşlı H, Aydemir Ş. Prevalence of blaPER-1 and integrons in ceftazidime-resistant gram-negative bacteria at a university hospital in Turkey. Jpn J Infect Dis 2013; 66(2): 146-8.

26. Xu Z, Li L, Shirtliff ME, et al. Occurence and characteristics class 1 and 2 integrons in Pseudomonas aeruginosa isolates from patients in Southern China. J Clin Microbiol 2009; 47(1): 230-4.

27. Gu B, Tong M, Zhao W, et al. Prevalence and characterization of class I integrons among Pseudomonas aeruginosa and Acinetobacter baumannii isolates from patients in Nanjing, China. J Clin Microbiol 2007; 45(1): 241-3. 